\title{
FINANCING SUSTAINABLE GROWTH AND BUILDING THE CAPITAL MARKETS UNION IN THE EUROPEAN UNION
}

\begin{abstract}
The European Union is trying to make environmental, social and corporate governance (ESG) central to its financial system. Investments, which flow through the capital market, should favour sustainable development. The closing of the investment gap in sustainable investment is one of the priorities on the way to the sustainable growth of the EU economy. Very unfortunately, sustainable finance has been made part of the plan to build the capital markets union. In my opinion, including sustainable finance in this process is a misguided solution. The aim of this article is to analyse the conditions of including sustainable finance in the process of building the capital markets union. Since the subject discussed in the article is completely new, the author did not consult any academic studies that could have acted as a point of reference in the conducted analyses. The article can be seen as a pioneering study intended to contribute to fill the gap in this area.
\end{abstract}

Keywords: sustainable finances, sustainable investments, sustainable development, capital markets union, European Union.

JEL Classification: F36, G15, Q56.

\section{Introduction}

World economies compete to achieve the highest growth dynamics possible, and higher GDP per capita is usually equated with increased

Małgorzata Janicka, University of Lodz, Department of International Finance and Investment, Polskiej Organizacji Wojskowej 3/5, 90-255 Łódź, Poland, e-mail: malgorzata.janicka@uni.lodz.pl, ORCID: https://orcid.org/0000-0003-2199-0093.

This is an open access article distributed under the terms of the Creative Commons Attribution-NonCommercial-NoDerivatives 4.0 License (CC BY-NC-ND 4.0); https://creativecommons.org/ licenses/by-nc-nd/4.0/. 
citizens' welfare. Every year we have rankings showing which countries are the top competitors. Unfortunately, there are no rankings that would tell us what environmental and social cost of acceleration in economic growth is borne by the individual countries. Currently, the European Union has launched, for the first time on such a scale, an action plan on funding sustainable growth. The move is unprecedented because the plan is a response to another European initiative: creation of the capital markets union. Free movement of capital is usually seen in light of its optimal allocation understood as the potentially highest rate of return achievable at a certain assumed level of investment risk. According to common belief, financial markets are driven by greed. This belief is fully justified if we look at the causes, scale and depth of the global financial crisis of 2008+. By incorporating goals connected with financing the sustainable growth of EU Member States into the plan of building the capital markets union, the EU has sent a remarkable signal about how it perceives the role of the capital market in the economy. Nowadays, the market has acquired a new mission that previously was not defined so explicitly. The EU wants environmental, social and governance issues (ESG) to become central elements of the financial system. The EU economy is expected to develop into an environmentally-friendly and resilient circular ecosystem. Investments which flow through capital markets should favour sustainable growth, which means that investors should consider ESG aspects such as greenhouse gas emissions, depletion of natural resources, and working conditions in their decision-making. This recommendation is addressed especially to institutional investors who should inform their clients how the above-mentioned aspects are considered in their decisions. The closing of the investment gap in sustainable investment is one of the priorities that must be accomplished on the way to the sustainable growth of the EU economy. The problem is that, very unfortunately, sustainable finance has been made part of the plan to build the capital markets union, starting from the assumption that boosting the dynamics of capital market development and the resultant volume of investment resources obtained through them will also help to increase the volume of funds for sustainable investment.

The aim of this article is to analyse the conditions of including sustainable finance in the process of building the capital markets union. Since the subject discussed in the article is completely new (there are no similar cases in other countries), the author did not consult any academic studies that could have acted as a point of reference in the conducted analyses. The article is intended to help fill the gap in this area. Qualitative research 
methods have been used - a review and analysis of the available sources (legal acts, reports, articles and other documents) related to sustainable finance and the capital markets union in the European Union.

\section{Free Movement of Capital and the Capital Markets Union}

Legally free movement of capital within the EU was put in place in May 1994 when Greece abolished the remaining restrictions. We need to stress that although the elimination of legal barriers to the free movement of capital is a precondition for deepening the integration of capital markets, it is not enough. If it were enough, subsequent activities undertaken by the EU in this area since 1999 would have been redundant (for more, see: Janicka 2018, pp. 195-206). Nowadays, whenever a new country joins the EU, it must abolish all restrictions to the free movement of capital (with the exception of jointly agreed exemptions maintained throughout the transition period), meaning that formal barriers are no longer obstacles to the deepening of de facto integration. However, another plan in this area - the building of the capital markets union - proves that the EU is not satisfied with the existing level of integration. "Despite significant progress in recent decades to develop a single market for capital, there are still many long-standing and deep-rooted obstacles that stand in the way of cross-border investments. These range from obstacles that have their origins in national law insolvency, collateral and securities law - to obstacles in terms of market infrastructure, tax barriers and changes in the regulatory environment that undermine the predictability of rules for direct investments" (European Commission 2015a, p. 23).

At the same time, in accordance with earlier commitments (Council Directive 88/361 of 24 June 1988 for the implementation of Art. 67 of the Treaty; Treaty on the European Union, signed on 7 February 1992 and ratified on November 1993, OJ C 191 of 29.07.1992), the EU Member States opened themselves up to flows of capital with third countries. Unlike liberalisation of the flow of goods, where both parties are expected to facilitate access to their respective markets, for capital flows the EU Member States did not demand the principle of mutuality to be met. The early 1990s were a period when developed countries had no reason to fear for their position in the global economy. They had the most developed and rich financial markets and no developing economy could undermine their dominance in this field. Under such circumstances, not only did this one-sided opening to capital flows entail no risk to the EU, but it could also 
produce concrete benefits resulting from a more liberal approach on the part of third countries to the inflow of funds from the EU. The situation changed in recent decades when developing countries, in particular China, became the principal sources of capital in the global economy. Chinese capital stock is largely controlled by the central government (FX reserves), while Chinese investments are not always guided by the criterion of optimal allocation of capital. By maintaining barriers to entry into their market and taking advantage of the opening of the EU, China started to invest in the EU economies, including in sectors that these countries perceive as sensitive (Popławski 2017). As a result, the EU Member States had to review their policy of openness to capital flows from the external environment and undertake measures in the internal market to foster the position and role of capital markets in their respective economies. The effects of the opening, hitherto unknown to developed countries (and not always favourable for capital recipients), provoked the need to reconsider EU policy vis-à-vis the inflow of investment/capital.

\section{Financing Sustainable Growth}

The EU's action plan to build the capital markets union only marginally addresses the issue of financing sustainable growth. It only states that "efficient financial markets can help investors to make well informed investment decisions, and analyse and price long term risks and opportunities arising from the move towards a sustainable and climate friendly economy. This shift in investment can contribute towards delivering the 2030 climate and energy policy objectives and the EU's commitments on the Sustainable Development Goals" (European Commission 2015a, p. 17). In September 2016 the Commission presented another document "Capital Markets Union - Accelerating Reform", in which it once again only briefly referred to the financing of sustainable growth: "Reforms for sustainable finance are necessary to support investment in clean technologies and their deployment, ensure that the financial system can finance growth in a sustainable manner over the long term, and contribute to the creation of a low-carbon, climate resilient economy. Such reforms are essential to meet our climate and environment objectives and international commitments (...)" (European Commission 2016, pp. 5-6).

The key document on financing sustainable growth, which resulted from earlier identified goals connected with the building of the capital markets union, was published in March 2018 under the title "Commission Action 
Plan on Financing Sustainable Growth" (SF) (European Commission 2018a). To start with, we need to focus on the term "sustainable finance". In accordance with the definition included in the document, "sustainable finance generally refers to the process of taking due account of environmental and social considerations in investment decision-making, leading to increased investments in longer-term and sustainable activities" (European Commission 2018a). In other words it is about Socially Responsible Investment (SRI), a term already present in the subject literature, which nowadays is being replaced with: sustainable investment or responsible investment or the broadest term - "sustainable finance" (Sustainable Finance Glossary 2018). The term "sustainable finance", if not explained properly, may be misleading, especially when rendered in other languages, as it may be understood as a way of financing an investment, e.g. the relationship between own and external capital in the project in question. A similar mental shortcut is also used in relation to, e.g. the terms "sustainable capital market" or "sustainable financial market". These terms may be interpreted contrary to the intentions of those who have coined them. Sustainable market, i.e. a market which is balanced, which develops harmoniously without serious tensions, can be presented in picturesque terms as a flattened financial cycle. Such an interpretation fundamentally differs from seeing a sustainable capital market as a market which acts as a broker in transferring funds for ESG investment. Yet the detailed goals of SF leave no room for doubt as to what planned activities refer to (European Commission 2018a, p. 2).

One of the key terms that crops up many times in the plan is the so-called circular economy. In accordance with the interpretation of the European Commission (European Commission 2015b), the circular economy is a production and consumption model, which consists in sharing, borrowing, reuse, repairing, refurbishing and recycling materials and products as long as it is possible and expanding the product lifecycle. When a product lifecycle is coming to an end, raw materials and waste from this product should remain in the economy, as they can be reused easily, which in practice may mean reducing waste to a minimum. Such approach contrasts with a traditional, linear economic model based on the "take - make - use dispose" model and large quantities of cheap and easily available materials and energy. So-called "planned obsolescence", i.e. designing products which do not work beyond a specific time horizon, is an element of the model (Gospodarka o obiegu zamkniętym 2018). Transforming the current economic model, which aims at increasing consumption, into a model of 
limited consumption adapted to one's needs and at the same time extending the product lifecycle are surely justified postulates. However, there is serious doubt as to whether under the current model of how economies and societies operate, particularly in developed countries, these postulates can really be accomplished. The extension of the product lifecycle means the need to restrict the production of consumer goods because they are used/work longer (especially electronic and electrical equipment); moreover, it means a change in the approach to how they are constructed: instead of closed models, which must be replaced as units, we need individual components, which can be replaced to repair products, which not long ago we would have thrown away. Nowadays, many products are replaced not because they have really got physically worn out, but because of their moral wear and tear. Under the above circumstances, the following question arises: what arguments can convince companies to choose this business model? Smaller sales and production not only mean potentially smaller employment but also smaller profits and income of company owners (including shareholders). If we agree that the capital market informs us about a company's current value, e.g. by revealing its financial performance, one can easily imagine a situation in which shareholders who declare that SRI and CSR are ideas relevant to them, in reality dispose of a company's shares when they cannot secure a satisfactory rate of return. If a company's output and profits are decreasing, the situation can be reversed either by increasing the number of customers who buy its products or by increasing prices. Both possibilities are strongly limited - the first by natural conditions, the second by competition in the market. Low quality goods are still being bought by many purchasers with limited financial resources, for whom price is the main selection criterion. In the market, we can find products that comply with the CSR idea: environmentally-friendly food, clothes and cars. The market for these goods exists and is on the rise although it still represents a small chunk of the traditional market and the main barrier is the price, which is higher than the market average. In capital markets, specifically in the stock market, we have indices that include companies that meet CSR requirements (e.g. the Dow Jones Sustainability Index series, Calvert Social Index, Johannesburg Stock Exchange Socially Responsible Index, Sao Paolo Stock Exchange Corporate Sustainability Index, KLD Global Sustainability Index Series, and Respect Index). However, the vast majority of investors continue to focus on traditional stock indices. The "critical mass" of CSR companies has not been exceeded yet in the capital markets. 
Careful examination of the action plan for sustainable finance also encourages reflection to the effect that it clearly addresses to an insufficient degree an issue that is crucial from the point of view of sustainable finance: the strategy of influencing consumers' and investors' choices. The choices made by these two groups, which often intertwine, will be decisive for the success of the plan. I do not share the optimism which permeates the "Final Report 2018 by the High-Level Expert Group on Sustainable Finance", according to which: "There is strong evidence that Europe's citizens overwhelmingly believe that social and environmental objectives are important for their savings and investments" (Financing a Sustainable European Economy 2018). This conclusion was drawn from analyses of CSR and SRI carried out by a variety of institutions. One of these analyses can be found in the Mind Shift study (2017) prepared by NATIXIS, one of the world's largest asset management firms. According to the study, individual investors are very much interested in SRI, but unfortunately it does not tell us which countries these investors come from. The are most probably not only from European countries because the research was conducted on a global scale: "Among the 7,100 individuals from 22 countries who were included in our 2016 Global Survey of Individual Investors, we find a consistent belief that it is important to address ESG factors in their investments" (Mind Shift..., p. 7). It is a pity that detailed information about the research sample (broken down only by generation and gender) was not provided directly in the study as it may be vital for final conclusions. If the sample had included mainly respondents from developed countries with relatively high income and education, such answers would come as no surprise, especially that the given study covered active investors. From the point of view of successful delivery of the plan, the key lies in bringing the message to the biggest group of the youngest recipients: education for the future is in this case the key challenge. Future consumers and investors must realise the close relationship between the choices they make and how their environment works at the social and environmental levels. To most, the ESG criteria are important. Nevertheless, the question arises as to how many consumers and investors are guided by them when making purchasing decisions and investing their money. Environmentally-friendly purchases will eliminate non environmentally-friendly manufacturers, while SRI forces companies to observe ESG standards. Yet one may get the impression that the SF plan focuses on the final element of the investment process - the company which receives capital. By the same token, the assumption is made that the main problem of insufficient financing for ESG companies lies in 
clogged investment flow channels rather than in investors' lack of interest in increasing its volume. It is an optimistic assumption.

An important aspect which the SF action plan draws attention to is so-called "greenwashing", i.e. using marketing to present the products, activities or strategies of an organisation as environmentally-friendly when in reality they are not. This issue is very much relevant to combining financial markets with sustainable growth financing. In May 2018 the draft of the Regulation on the Establishment of a Framework to Facilitate Sustainable Investment (European Commission 2018b) was put on the table. As one can read in this proposal, its goal is to eliminate divergences in the existing national taxonomies and address market-based initiatives at the national level to reduce the risk of "greenwashing", make it easier for economic operators to raise funds for environmentally-sustainable activities across borders, and to establish a level playing field for all market participants. Financial market participants who offer financial products labelled as environmentally-sustainable investments or investment products exhibiting similar characteristics will have to make it clear to investors why these products can be considered environmentally sustainable based on uniform criteria established at the EU level (European Commission 2018b, pp. 5-6). This Regulation is fundamental for sustainable finance; the absence of clear-cut definitions and criteria for companies that meet ESG requirements results in the discretionary interpretation of terms from the realm of sustainable development and their unauthorised use in order to promote business.

Summing up: the emerging capital markets union should help to increase the volume of investment earmarked for developing undertakings within the sustainable finance framework, which will help to implement the idea of transforming the European Union economy from the linear to the circular model.

\section{Sustainable Finance and the Capital Market: Potential Problems and Ramifications}

Although the expected increase in the volume of investments meeting ESG criteria is a fully justified objective, combining the two plans - building the capital markets union and developing sustainable finance - should be considered a rather risky initiative. In accordance with the traditional approach, investors ready to accept low risk choose bank products while those prepared to accept higher risk choose capital market instruments. Since 
it is believed that the efficiency of the transmission of investment resources in a market economy is lower for the banking sector compared to the capital market, it is no wonder that the EU wishes to change the model of the financial system from bank-oriented to market-oriented similarly to the United States. The EU is still dominated by the continental banking system; it is not the first attempt made by the EU to change the model and so far it has not been very successful. Surprisingly, successive plans to deepen capital market integration lack references to one of the fundamental issues: the readiness of capital providers from the EU to accept higher levels of investment risk, as is the case in the United States. In accordance with the maxim "there is no such thing as a free lunch" - I expect more but I risk more. The building of the capital markets union is expected to provide the framework that will facilitate flows of investment capital within the EU as much as possible; investors will have more options to select investments with diverse profit/risk parameters and a different time horizon. The interweaving of sustainable finance into the process makes these parameters less transparent. The plan for sustainable finance reads: "Investment decisions are typically based on several factors, but those related to environmental and social considerations are often not sufficiently taken into account, since such risks are likely to materialise over a longer time horizon. It is important to recognise that taking longer-term sustainability interests into account makes economic sense and does not necessarily lead to lower returns for investors" (European Commission 2018a p. 2). The lack of clarity in this paragraph is to a large extent the consequence of combining terms such as investor interest, interest of the economy, capital market, and sustainable finance. Environmental projects often require long-term engagement, and the investment outlays involved in environmentally-friendly companies may be higher than in businesses which do not apply such solutions. However, such investments are justified by the economic and social interests of the country. Investors who expect a particular rate of return over a specific, not necessarily long-term time horizon will most probably not be interested in them, which is why environmentally-friendly investments are often financed from public funds. The statement that they "will not necessarily lead to lower returns for investors" is unclear. They do not have to lead to such consequences but they may. A new category has emerged in financial markets, which is more complex than the simple but legible category of profit: profit/environmental costs of generating profit (Janicka 2016, p. 7). Nevertheless, it is difficult to find analyses that would take it into account. The credibility of the operator and project predictability are key elements of each investment decision. Private capital should be attracted to SRI after 
all the ramifications/risks connected with such investments have been made clear, and reference should be made to values other than the rate of return. In order for SRI not to remain only a side stream of investments targeting eccentric or socially responsible investors, it is crucial to introduce the ESG requirements into the economy universally and monitor their implementation. Cases of inhuman working conditions approved by international holdings in developing countries or exceeded safe limits of harmful substances in fuel gases hidden by corporations have undermined trust in the implementation of CSR principles by the companies which declare such efforts. "Just recently, the governor of the Bank of England, Mark Carney, called for the financial system to adapt quickly, smoothly and effectively to social needs and particularly to climate-change issues. The Banque de France, which has just announced a responsible investment charter, is committed to taking things even further than supporting green assets to actually penalising climatedamaging ones ('brown assets')" (Revelli 2018). If companies are supposed to modify their operating model and switch to a system compliant with ESG requirements, appealing for change is not enough. The market, also the financial market, must clearly formulate its expectations and then enforce them completely.

Affluent investors in developed countries (but surely also in some developing ones) are certainly willing to allocate some of their resources to sustainable investment if they feel that they are delivering a mission and that they are part of a bigger group that understands this mission and approves of it. Yet, as The Economist rightly observes: "But the more fundamental question is the trickiest to solve, because it boils down to ethics rather than finance. How can the relative value of, say, educating a girl in the developing world be compared with preventing a tonne of air pollution? In the end, investors' choices among the different variants of sustainable investments will be driven by their own personal interests, rather than just by financial calculations" (What Is Sustainable Finance? 2018).

I would like to stress that building the capital market union does not exclude sustainable finance. However, if the EU wants to develop its capital markets, it should first focus on this task to avoid a situation in which the implementation of two diverse objectives leads to failure. In the context of these considerations, it is worth quoting the most puzzling excerpt from the SF plan: "Despite the efforts made by several European companies, undue short-term market pressures may make it difficult to lengthen the time horizon in corporate decision-making. Corporate managers may become overly focused on short-term financial performance and 
disregard opportunities and risks stemming from environmental and social sustainability considerations. As a consequence, the interactions between capital market pressures and corporate incentives may lead to unnecessary exposure in the long-term to sustainability risks. The Commission will engage with all relevant stakeholders to analyse this issue more closely" (European Commission 2018a, p. 13). This paragraph shows that the authors of the plan have probably not fully grasped the operating principles of capital markets. Short-term investments/transactions are inherent components of these markets as they generate market liquidity. If investors invested their financial resources only for the long-term, trading on the markets would die out completely and then the capital market would fail to deliver its primary functions: mobilisation, evaluation and transformation of capital. The freedom of market participants to operate is fundamental to the growth of the capital market: no one can deprive them of the right to withdraw from an investment at any time, and similarly no one can restrict the time horizon of an investment, since it is subject to agreement between the capital recipient and the capital provider. Under these circumstances we can clearly see that, for the purposes of sustainable growth, banking sector financing is a far better option because it sees long-term investment projects as a standard solution and loan agreements are different by nature from capital market instruments. The question is why combine sustainable finance with the capital market, which is ruthless and very dynamic and which holds corporate boards accountable for, among others, failed short- or long-term decisions? The investigation into the content of the plan suggests that perhaps the point is to develop the market of investment funds working towards the accomplishment of sustainable investment principles and ideas that should increasingly replace the financing of ESG projects from public funds ${ }^{1}$ with private investment, especially in the face of the deepening investment gap $^{2}$. In fact, investment funds are capital market operators, but there is no coincidence between their operations and the "undue short-term pressure from capital markets" (European Commission 2018a, p. 3). We should not equate all capital market activities with sustainable finance.

\footnotetext{
1 "The EFSI has proven to be instrumental in crowding in private investment for strategic projects across the EU, mobilising almost EUR 265 billion in total investments. Following its successful first years of operation, the EFSI has been recently extended until 2020 (EFSI 2.0) and its investment target has been raised to half a trillion euros" (European Commission 2018a, p. 7).

2 "Europe has to close a yearly investment gap of almost EUR 180 billion to achieve EU climate and energy targets by 2030. According to estimates from the European Investment Bank (EIB), the overall investment gap in transport, energy and resource management infrastructure has reached an astounding yearly figure of EUR 270 billion” (European Commission 2018a, p. 3).
} 
The growth in sustainable investment and the increasing share of its volume should follow evolutionary rather than revolutionary patterns. The trend is reflected in the data (see Table 1). A clear rising trend is observed for the absolute value of assets of the European Responsible Investment Funds and for the share of this market in the total European market of investment funds. It is not a quantum leap, but the change is indicative of the growing importance of SRI among classical investment solutions.

Table 1. The Investment Funds Market in Europe, 2010, 2012, 2014 and 2016

\begin{tabular}{l|c|c|c|c}
\hline \multicolumn{1}{c|}{ Specification } & 2010 & 2012 & 2014 & 2016 \\
\hline $\begin{array}{l}\text { Net Assets of European Investment Funds (billion } \\
\text { EUR) }\end{array}$ & 8573 & 9468 & 12030 & 14142 \\
\hline $\begin{array}{l}\text { Net Assets of European Responsible Investment } \\
\text { Funds (billion EUR) }\end{array}$ & 251 & 287 & 376 & 476 \\
\hline $\begin{array}{l}\text { Percentage of Net Assets of European Responsible } \\
\begin{array}{l}\text { Investment Funds in Net Assets of European } \\
\text { Investment Funds }\end{array}\end{array}$ & 2.9 & 3.0 & 3.1 & 3.6 \\
\hline
\end{tabular}

Source: author's own calculations based on data from Delbecque \& Carroll (2017, p. 3) and European Responsible Investing... (2017, p. 6).

The sustainable investment segment is one of elements of a broadly understood investment pool flowing through the capital market. For the time being it is rather a marginal, and not a dominant, part of capital market operations.

When it comes to the short-term driven approach exhibited by capital markets, in Action 10 we read: "The Commission invites the European Supervisory Authorities (ESAs) to collect evidence of undue short-term pressure from capital markets on corporations and consider, if necessary, further steps based on such evidence by Q1 2019. More specifically the Commission invites ESMA to collect information on undue short-termism in capital markets, including: (i) portfolio turnover and equity holding periods by asset managers; (ii) whether there are any practices in capital markets that generate undue short-term pressure in the real economy" (European Commission 2018a, p. 14). Since no ESMA report has been published in this field yet, it is hard to predict what evidence of practices exercised in the capital markets and leading to undue short-term pressure in the real economy will be collected. However, our observations of capital market operations in the real economy within the EU, including mainly the stock markets, suggest that it will not be difficult to collect such evidence. 
This is because, usually, whenever investors learn about poor the financial performance of companies they rapidly dispose of their assets; negative stock market indices reduce interest in investing in these markets, etc.; and all of this happens rapidly and within very short time spans. It would be interesting to know what measures will be put in place based on the collected evidence and how coherent they will be with the building of capital the markets union. In 2019 the Commission is due to release a report on the implementation of the SF Action Plan. In light of the above-presented doubts the report will make a very interesting contribution, especially its part dealing with the capital market. It is not clear to me:

- whether allegations of undue short-term pressure exerted by the capital market concern only sustainable investment or all investment,

- how entities that manage the assets will be held accountable for the period for which investments are made,

- whether there will be any regulations that restrict the freedom of financial market operators to choose the investment time horizon.

These and many other questions that arise from the analysis of the SF Action Plan are not just rhetorical. The answers to them are linked to the key EU initiative designed to shift the channel through which investment assets flow in the European economy, i.e. to the building of the capital markets union, which is expected to change the model by which the European financial system operates.

\section{Conclusions}

Harmful and highly alarming changes in the natural environment resulting from economic activity pursued by humans have become a challenge that must be faced by today's generations if we want future generations to live normally on our planet. Economic growth still takes precedence over caring for the natural environment, as is clearly demonstrated by the withdrawal of the United States from the so called the Paris Agreement on climate change in 2017. According to what we can read in the Agreement, the United States' share in global greenhouse gas emissions is approximately 18\%, putting it in second place in the ranking. China, with its approximately $21 \%$ share, is in first place (the EU as a whole generates approximately $12 \%$ of global emissions). Contrary to the decision of the United States, the EU has declared that it will be sticking to the Paris Agreement and is undertaking concrete steps to make the idea of sustainable growth a reality. One initiative that is part of this idea 
is the EU action plan for financing sustainable development. Undoubtedly, closing the investment gap in sustainable investment is one of the priorities that must be accomplished on the way to sustainable growth. The problem, however, is that the Commission has decided, very unfortunately, to include sustainable finance in the building of the capital markets union in the hope that by making capital market growth more dynamic and by increasing the volume of investment resources it will increase the volume of funds available for sustainable investment. Risk, profit and investment horizon are the principal categories considered by investors. The analysis of the Action Plan in the field of financing sustainable growth shows that sustainable investment may entail higher risk, lower potential profit, and a time horizon longer than for traditional investment projects. The authors of the plan would not only like investors to approve these changed parameters and shift resources to investments meeting ESG criteria, but would also like capital markets to stop exerting short-term pressure on the economy, whatever this postulate means. Challenging the operating principles of capital markets, which so far have not been restricted with any requirements as to the time horizon of transactions, questions the successful accomplishment of the building of capital markets union per se.

I believe that including sustainable finance in the process of building the capital markets union is not a good idea, especially in view of the conflicting messages about the role of capital markets that appear in both plans. In my opinion, the first best solution is the sequential implementation of the plans: first the completion of the capital markets union and then the implementation of sustainable finance ideas. The second best solution is the parallel, unconnected implementation of both plans.

\section{Bibliography}

Delbecque, B. and Carroll, A. (2017) Trends in the European Investment Fund Industry in the Fourth Quarter of 2016 \& Results for the Full Year of 2016. The European Fund and Asset Management Association, Quarterly Statistical Release, March, N68, https:// www.efama.org/statistics/SitePages/Statistics.aspx (accessed: 31 August 2018).

European Commission (2015a) 30 September 2015 COM(2015) 468 final Communication from the Commission to the European Parliament, the Council, the European Economic and Social Committee and the Committee of the Regions, Action Plan on Building a Capital Markets Union \{SWD(2015) 183 final\} $\{\mathrm{SWD}(2015) 184$ final\}, Brussels. 
European Commission (2015b) 2 December 2015 COM(2015) 614 final Communication from the Commission to the European Parliament, the Council, the European Economic and Social Committee and the Committee of the Regions, Closing the Loop - An EU Action Plan for the Circular Economy, Brussels.

European Commission (2016) 14 September 2016 COM(2016) 601 final Communication from the Commission to the European Parliament, the Council, the European Economic and Social Committee and the Committee of the Regions, Capital Markets Union - Accelerating Reform, Brussels.

European Commission (2018a) 8 March 2018 COM(2018) 97 final Communication from the Commission to the European Parliament, the Council, the European Economic and Social Committee and the Committee of the Regions, Action Plan: Financing Sustainable Growth, Brussels.

European Commission (2018b) 24 May 2018 COM(2018) 353 final 2018/0178 (COD) Proposal for a Regulation of the European Parliament and of the Council on the establishment of a framework to facilitate sustainable investment (Text with EEA relevance) $\{\operatorname{SEC}(2018) 257$ final $\}-\{\operatorname{SWD}(2018) 264$ final $\}-\{\operatorname{SWD}(2018) 265$ final $\}$, Brussels.

European Responsible Investing Fund Market 2016 Statistics (2017) April, https://home. kpmg.com/lu/en/home/insights/2017/04/european-responsible-investing-fundmarket-2016.html (accessed: 31 August 2018).

Financing a Sustainable European Economy (2018) Final Report by the High-Level Expert Group on Sustainable Finance Secretariat provided by the European Commission.

Gospodarka o obiegu zamkniętym [Circular Economy] (2018) http://www.europarl. europa.eu/news/pl/headlines/economy/20151201STO05603/gospodarka-o-obieguzamknietym-definicja-znaczenie-i-korzysci-wideo (accessed: 28 August 2018).

Janicka, M. (2016) "Financial Markets and the Challenges of Sustainable Growth". Comparative Economic Research. Central and Eastern Europe 19(2), pp. 27-41, https:// doi.org/10.1515/cer-2016-0011.

Janicka, M. (2018) "Capital Market Union - Perspectives on Changes in the Financial System Model in the European Union". Folia Oeconomica. Acta Universitatis Lodziensis 1(333), pp. 195-206, https://doi.org/10.18778/0208-6018.333.13.

Mind Shift. Getting Past the Screens of Responsible Investing (2017) https://www.im. natixis.com/intl/research/environmental-social-governance-survey-findings (accessed: 22 August 2018).

Popławski, K. (2017) Kapitat ma narodowość: obawy w Niemczech wobec chińskich inwestycji. Warszawa: Ośrodek Studiów Wschodnich, https://www.osw.waw.pl/pl/publikacje/komentarze-osw/2017-01-25/kapital-ma-narodowosc-obawy-w-niemczechwobec-chinskich (accessed: 27 August 2018).

Revelli, Ch. (2018) Academia to be Accountable for Sustainable Finance, https://www. socialsciencespace.com/2018/06/academia-must-take-action-for-responsible-sustainablefinance/ (accessed: 30 August 2018).

Sustainable Finance Glossary (2018) http://www.sustainablefinance.ch/en/glossary-_ content---1--3077.html (accessed: 31 August 2018).

What Is Sustainable Finance? (2018) The Economist Explains, https://www.economist.com/ the-economist-explains/2018/04/17/what-is-sustainable-finance (accessed: 31 August 2018). 


\section{Abstract}

\section{Finansowanie zrównoważonego rozwoju wobec budowy unii rynków kapitałowych w Unii Europejskiej}

Unia Europejska zmierza do tego, by uczynić kwestie z zakresu ochrony środowiska, polityki społecznej i ładu korporacyjnego (environmental, social and governance, ESG) centralnymi elementami systemu finansowego. Likwidacja luki inwestycyjnej odnoszącej się do zrównoważonych inwestycji jest jednym z priorytetów na drodze prowadzącej do zrównoważonego rozwoju gospodarki UE. Niefortunnie postanowiono jednak włączyć kwestie zrównoważonych finansów (sustainable finance) w proces pogłębiania integracji rynków kapitałowych w Unii Europejskiej. Zdaniem autorki artykułu nie jest to dobre rozwiązanie. Celem publikacji jest analiza uwarunkowań i zasadności włączania sustainable finance $\mathrm{w}$ proces budowy unii rynków kapitałowych. Ponieważ podjęty w artykule temat jest zupełnie nowy, brakuje opracowań i artykułów naukowych, które mogłyby stanowić odniesienie dla prowadzonych w niniejszym artykule analiz. Publikacja ta ma przyczynić się do wypełnienia istniejącej w tym zakresie luki.

Słowa kluczowe: zrównoważone finanse, zrównoważone inwestycje, zrównoważony rozwój, unia rynków kapitałowych, Unia Europejska. 